\title{
Causation studies for Kapas yield, yield components and lint quality traits in Mexican cotton (Gossypium hirsutum L.)
}

Mudhalvan. S 网

Department of Genetics and Plant Breeding, CPBG, TNAU, Coimbatore, India

S. Rajeswari

Department of Cotton, CPBG, TNAU, Coimbatore, India

L. Mahalingam

Department of Cotton, CPBG, TNAU, Coimbatore, India

P. Jeyakumar

Department of Plant Physiology, TNAU, Coimbatore, India

M. Muthuswami

Department of Agricultural Entomology, TNAU, Coimbatore, India

N. Premalatha

Department of Cotton, CPBG, TNAU, Coimbatore, India

\begin{tabular}{|c|c|}
\hline ARTICLE INFO & ABSTRACT \\
\hline $\begin{array}{l}\text { Received : } 23 \text { July } 2021 \\
\text { Revised : } 31 \text { August } 2021 \\
\text { Accepted : } 07 \text { September } 2021 \\
\text { Available online: } 19 \text { December } 2021 \\
\text { Key Words: } \\
\text { Correlation } \\
\text { Genotypic } \\
\text { Path coefficient } \\
\text { Phenotypic }\end{array}$ & $\begin{array}{l}\text { Cotton is a very important crop that consists of traits with different } \\
\text { associationship due to genetic and environmental factors. In order to determine } \\
\text { the degree of association between seed cotton yield and important traits, a } \\
\text { study was done using an RBD experiment with } 30 \text { hybrids. Seed cotton yield, } \\
\text { plant height, GOT, number of sympodial braches, boll weight, bolls per plant, } \\
\text { span length, fineness and strength data were collected and analysed. The } \\
\text { experiment was done with } 30 \mathrm{~F}_{1} \text { hybrids have delivered through Line } x \text { Tester } \\
\text { mating configuration utilizing six lines and five testers were planted in a } \\
\text { Randomized Block Design (RBD) with two replications at the Department of } \\
\text { Cotton, TNAU, Coimbatore. Seed cotton yield per plant was found to have } \\
\text { significant positive genotypic connection with boll weight }(0.5810) \text {, number of } \\
\text { bolls per plant (0.3867), plant height }(0.422) \text { and ginning percent }(0.2182) \\
\text { however altogether and contrarily related with consistency proportion at } \\
\text { genotypic level. The phenotypic relationship esteems likewise uncovered that } \\
\text { seed cotton yield per plant had highly huge and positive phenotypic connection } \\
\text { with number of bolls per plant }(0.3470) \text { and boll weight }(0.4763) \text {. Path } \\
\text { coefficients were processed to assess the commitment of individual characters } \\
\text { to yield in cotton. The way investigation demonstrated high certain immediate } \\
\text { impact of number of bolls per plant }(0.4743) \text { and fiber strength }(0.6880) \text { on seed } \\
\text { cotton yield. Micronaire value displayed high sure circuitous impact on seed } \\
\text { cotton yield through range length }(0.3393) \text {, the outcome showed that number of } \\
\text { bolls per plant had a high sure relationship with seed cotton yield and } \\
\text { sympodial per plant recorded low certain connection with seed cotton yield. It } \\
\text { was therefore concluded that selection of high yielding cotton hybrids could } \\
\text { emphasize more on lint yield, boll weights, plant height and bolls per plant for } \\
\text { better-performing lines. Gin outturn and fibre strength could be used } \\
\text { indirectly to improve seed cotton yield through other traits. }\end{array}$ \\
\hline
\end{tabular}

\section{Introduction}

Cotton (Gossypium hirsutum L.) also renowned as most important fibre cum food crop. Cotton "White Gold" belongs to family Malvaceae is improvement programmes across the world have grown mainly in the tropics and sub-tropics as the always responded to the needs of the growers and

Corresponding author E-mail: muthalvanshanmugam2012@gmail.com

Doi: https://doi.org/10.36953/ECJ.2021.22341

This work is licensed under Attribution-Non Commercial 4.0 International (CC BY-NC 4.0)

(C) ASEA 
industry and strived to combine high yield and good fibre quality. In India, development of high yielding cotton varieties with superior fibre quality is a fundamental objective of many cotton improvement programmes. Hence the objective of the present study is to explore the association between various yield and fibre quality traits to facilitate indirect selection in cotton (Angadi et al., 2016).

In plant breeding correlation studies pave the way for a better understanding of the association prevailing between highly heritable characters with most economic characters and give better understanding of the contribution of each trait in building up the genetic make-up of the crop (Jawahar and Patil, 2017). Since, seed cotton yield and fibre quality traits are complex quantitative characters, direct selection may not be a reliable approach as these traits are influenced by environmental factors. So it is important for breeders to know more about direct and indirect correlation among the different traits while selecting plants for breeding. Path coefficient analysis provides an effective aid in selection as it parts the correlation into direct and indirect components. So it's important to know more about the traits which contribute to the yield and their direct and indirect association to successfully design an effective breeding program. It is helpful in the procedure of selection and empowers the breeders to select a genotype on the basis of two or more traits simultaneously (Salahuddin et al., 2010).

The present research was conducted on $30 \mathrm{~F}_{1}$ hybrids to study the correlation and path coefficient analysis of fifteen yield, yield attributing and fibre quality traits to find the principal yield determining components and to use these traits as selection criteria for seed cotton yield improvement.

\section{Material and Methods}

This experiment was directed during summer 2020 at Department of cotton, TANU, Coimbatore. The result including 30 hybrids alongside check (Mallika) was spread out in Randomized Block Design (RBD) with two replications. Each cross was planted in two columns of $5 \mathrm{~m}$ length with a separating of $90 \times 60 \mathrm{~cm}$. Five plants from each genotypes were selected from each replications randomly for examining the biometrical observations viz., plant height $(\mathrm{cm})$, number of sympodial branches per plant, number of bolls per plant, boll weight $(\mathrm{g})$, ginning outturn $(\%)$, span length $(\mathrm{mm})$, micronaire value $(10-6 \mathrm{~g} / \mathrm{in})$, fiber strength (g/tex) and seed cotton yield per plant(g).

Samples were ginned and their lint used for fibre quality traits in each replications with minimum ten grams of lint sample using High Volume Instrument (HVI)900 classic viz., Span length (mm) were observed. After thinning one plant per hill was maintained and all normal agronomic and cultural practices were done at the right time. The mean data collected from entire hybrids were subjected to estimate the correlation and path analysis using TNAUSTAT statistical analysis software. The total variance was partitioned into replication and treatment for all those seven characters. The mean data were tabulated for yield contributing traits and analysis of variance (ANOVA), estimation of critical difference and standard error were reported in tables for discussion. Heterosis were evaluated standard heterosis (standard hybrid) values. The observed mean data were statistically calculated by TNAUSTAT software.

Analysis of covariance was computed in a fashion similar to that of analysis of variance formula and the statistics were utilized in calculating, phenotypic and genotypic correlation coefficients. Genotypic and phenotypic relationship among different characteristics was determined utilizing the recipe given by Singh and Narayanan (1993). Way coefficient investigation (Dewey and $\mathrm{Lu}$, 1959) was done to translate the immediate and backhanded impacts of yield crediting and fiber quality attributes on seed cotton yield.

\section{Results and Discussion \\ Association among seed cotton yield and its attributing characters \\ Correlation coefficient analysis}

The genotypic and phenotypic correlation coefficients over ten biometrical traits were calculated for all entries and results are presented in Tables 1 and 2.

Genotypic correlation between seed cotton yield and other biometrical traits

The coefficients of genotypic correlation for seed cotton yield exhibited high and positively significant associations with boll weight (0.5810), number of bolls per plant (0.38) and plant height 
Table 1: Genotypic correlation coefficients among seed cotton yield and attributing characters in cotton hybrids.

\begin{tabular}{|l|l|l|l|l|l|l|l|l|l|}
\hline Traits & $\mathbf{Y}_{\mathbf{2}}$ & $\mathbf{Y}_{\mathbf{3}}$ & $\mathbf{Y}_{\mathbf{4}}$ & $\mathbf{Y}_{\mathbf{5}}$ & $\mathbf{Y}_{\mathbf{6}}$ & $\mathbf{Y}_{\mathbf{7}}$ & $\mathbf{Y}_{\mathbf{8}}$ & $\mathbf{Y}_{\mathbf{9}}$ & $\mathbf{Y}_{\mathbf{1 0}}$ \\
\hline $\mathbf{Y}_{\mathbf{1}}$ & -0.0187 & $0.4384^{* *}$ & -0.0290 & $0.2205^{*}$ & 0.1602 & 0.0146 & $-0.6138^{* *}$ & 0.1146 & $0.3799^{* *}$ \\
\hline $\mathbf{Y}_{\mathbf{2}}$ & $\mathbf{1 . 0 0}$ & $0.7388^{* *}$ & $0.5446^{* *}$ & 0.0991 & $-0.4685^{* *}$ & 0.1392 & $0.3947^{* *}$ & -0.1058 & -0.1758 \\
\hline $\mathbf{Y}_{\mathbf{3}}$ & & $\mathbf{1 . 0 0}$ & -0.1213 & $0.2584^{*}$ & 0.0993 & $-0.2069^{*}$ & -0.1159 & $0.2171^{*}$ & $0.3867^{* *}$ \\
\hline $\mathbf{Y}_{\mathbf{4}}$ & & & $\mathbf{1 . 0 0}$ & -0.1283 & $0.5480^{* *}$ & 0.0249 & $0.4278^{* *}$ & -0.1803 & $0.5810^{* *}$ \\
\hline $\mathbf{Y}_{\mathbf{5}}$ & & & & $\mathbf{1 . 0 0}$ & $-0.3379^{* *}$ & -0.1595 & -0.0205 & $0.2552^{*}$ & $0.2182^{*}$ \\
\hline $\mathbf{Y}_{\mathbf{6}}$ & & & & & $\mathbf{1 . 0 0}$ & -0.0631 & $0.7974^{* *}$ & $-0.4952^{* *}$ & 0.0460 \\
\hline $\mathbf{Y}_{\mathbf{7}}$ & & & & & & $\mathbf{1 . 0 0}$ & $0.2469^{*}$ & $-0.2918^{*}$ & - \\
\hline $\mathbf{Y}_{\mathbf{8}}$ & & & & & & & $\mathbf{1 . 0 0}$ & $-0.7211^{* *}$ & $0.0650^{* *}$ \\
\hline $\mathbf{Y}_{\mathbf{9}}$ & & & & & & & & $\mathbf{1 . 0 0}$ & -0.0487 \\
\hline
\end{tabular}

* = Significant at $5 \%$ level of Probability, ** $=$ Significant at $1 \%$ level of Probability

$\mathbf{Y}_{1}$

$\mathrm{Y}_{2} \quad$ - $\quad$ Number of Sympodial branches per plant

$\mathbf{Y}_{5}$

Ginning outturn (\%)

$\mathbf{Y}_{3}$

- Number of bolls/ plant

$\mathrm{Y}_{6} \quad-\quad$ Span length (mm)

$\mathrm{Y}_{4} \quad-\quad$ Boll weight (g)

$\mathrm{Y}_{9} \quad-\quad$ Micronaire value $\left(10^{-6} \mathrm{~g} / \mathrm{in}\right)$

$\mathrm{Y}_{7} \quad$ - Uniformity ratio

$\mathrm{Y}_{8} \quad$ - $\quad$ Fibre strength(g/tex)

$\mathrm{Y}_{10} \quad$ - $\quad$ Seed cotton yield per plant $(\mathrm{g})$

Table 2: Phenotypic correlation coefficients among seed cotton yield and attributing characters in cotton hybrids

\begin{tabular}{|c|c|c|c|c|c|c|c|c|c|}
\hline Traits & $Y_{2}$ & $Y_{3}$ & $Y_{4}$ & $Y_{5}$ & $Y_{6}$ & $\mathbf{Y}_{7}$ & $Y_{8}$ & $Y_{9}$ & $Y_{10}$ \\
\hline$Y_{1}$ & -0.0154 & $0.3794 * *$ & -0.0243 & 0.1861 & 0.1490 & 0.0107 & 0.1138 & 0.1022 & 0.1802 \\
\hline$Y_{2}$ & 1.00 & 0.1231 & -0.0777 & 0.0738 & -0.0302 & 0.1345 & 0.0812 & -0.0739 & $-0.2601 *$ \\
\hline $\mathbf{Y}_{3}$ & & 1.00 & -0.0858 & 0.1772 & 0.0869 & -0.1826 & -0.1127 & 0.1242 & $0.3470 *$ \\
\hline$Y_{4}$ & & & 1.00 & -0.0358 & 0.0555 & -0.0487 & 0.1210 & -0.1518 & $0.4763 * *$ \\
\hline$Y_{5}$ & & & & 1.00 & -0.0120 & -0.1809 & 0.0121 & 0.0982 & 0.1749 \\
\hline$Y_{6}$ & & & & & 1.00 & -0.0744 & $0.7608 * *$ & $\begin{array}{l}- \\
0.4269 * *\end{array}$ & 0.0364 \\
\hline $\mathbf{Y}_{7}$ & & & & & & 1.00 & 0.2270 & -0.2049 & $-0.3684 * *$ \\
\hline $\mathbf{Y}_{8}$ & & & & & & & 1.00 & $-\overline{0.6345^{* *}}$ & $-0.5631 * *$ \\
\hline$Y_{9}$ & & & & & & & & 1.00 & -0.0618 \\
\hline
\end{tabular}

* = Significant at 5\% level of Probability, ** = Significant at 1\% level of Probability

$\mathrm{Y}_{1}$

$Y_{2} \quad-\quad$ Number of Sympodial branches per plant

$\mathbf{Y}_{3}$

$\mathbf{Y}_{4}$

- Number of bolls/ plant

- $\quad$ Boll weight (g)

$\mathrm{Y}_{9} \quad-\quad$ Micronaire value $\left(10^{-6} \mathrm{~g} / \mathrm{in}\right)$
$Y_{5}$

$\mathbf{Y}_{6}$

$\mathbf{Y}_{7}$

$\mathbf{Y}_{8}$

$Y_{10} \quad-\quad$ Seed cotton yield per plant (g)
Ginning outturn (\%)

Span length (mm)

Uniformity ratio

Fibre strength(g/tex) 
(0.37). Non-significant, positive correlation coefficients were reported span length (0.04) and fibre strength (0.06) Lastly, non-significance with negative correlation was observed in the trait number of sympodial branches per plant (-0.17).

Phenotypic correlation between seed cotton yield and other biometrical traits

Phenotypic correlation for seed cotton yield unveiled high, significant and positive associations with boll weight $(0.4763$ and number of bolls per plant (0.3470). Non-significance with positive correlation coefficients were observed for plant height (0.1802), ginning outturn (0.1749) and span length (0.0364). Significance with negative correlation coefficients were observed for number of sympodial branches per plant $(-0.2601)$, uniformity ratio (-0.3684) and fibre strength (0.5631).

\section{Path coefficient analysis}

Genotypic path analysis depicting direct and indirect effects of various yield and yieldcontributing traits are presented in Table 3 and Fig 1. The residual effect was estimated as 0.80 and therefore, the existing traits seemed to be adequate for rationalizing the variation over seed cotton yield.

\section{Direct effects}

Among ten biometrical traits studied, fibre strength (0.6880) alone recorded very high, positive direct effects on seed cotton yield. Number of bolls per plant (0.4743) recorded high and positive direct effects. In contrast, negative direct effects and high ranking was observed in symbodial branches per plant and boll weight. The trait ginning outurn showed moderate positive direct effects on seed cotton yield. The fibre quality traits viz. span length and uniformity ratio had low negative direct effects while micronaire value had negligible negative direct effects on seed cotton yield. The remaining traits such as fibre fineness, plant height had negligible positive direct effects on seed cotton yield.

\section{Indirect effects}

Plant height exhibited high positive indirect effect on seed cotton yield through number of bolls per plant (0.2080) and fibre strength (0.0783). Micronaire value had high positive indirect effect on seed cotton yield via span length (0.3393) and number of bolls per plant (0.1030). Uniformity ratio also showed high and positive indirect effects for yield across span length (0.0432). Similarly, ginning outurn (0.1226) and span length (0.0471) had high positive indirect effects on seed cotton yield while channelizing through number of bolls per plant. Boll weight obtained high positive indirect effect with seed cotton yield also through sympodial branches per plant $(0.0120)$. Number of bolls per plant (0.0659) and boll weight (0.0500) contributed high indirect positive effect on seed cotton yield linking number of symbodial branches per plant. Micronaire value had high negative indirect effects $(-0.450)$ on seed cotton yield by means of fibre strength. Fibre strength reported high negative indirect effects $(-0.1327)$ on seed cotton yield, through uniformity ratio. Plant height had contributed indirectly high negative effects (0.1098 ) on seed cotton yield enrouting upon span length. Similarly, boll weight $(-0.0680)$ also reported high negative indirect effects on seed cotton yield while funneling down via span length. Number of sympodial branches per plant also showed high negative indirect effects $(-0.0373)$ on seed cotton yield across number of bolls per plant.

\section{Genotypic correlation}

The genotypic connection of seed cotton yield with different segment qualities in this hybrids is introduced in Table 1. Among yield ascribing attributes, exceptionally sure genotypic and huge relationship of plant height was seen with number of bolls per plant (0.4384) and GOT\% (0.2205). Exceptionally negative and critical affiliation was recorded between plant height and fiber strength (0.6138). The quantity of sympodial branches per plant was found to have profoundly significant and positive connected with number of bolls per plant (0.7388) and boll weight (0.5446) and thusly contrarily associated with range length (- 0.4685). Additionally, boll weight had high certain and critical relationship with span length (0.5480) and fiber strength (0.4278). As opposed to this, GOT\% recorded high negative and huge relationship with span length (- 0.3379), yet showed positive critical connection with micronaire value (0.2552). Range length had high negative and huge connection with micronaire value (- 0.4952) and positive relationship with micronaire value $(0.7974)$. For different characters, consistency proportion showed high certain and critical relationship with fiber strength (0.2469) and micronaire value (0.2918). These result were in concurrence with the 
Table 3: Path analysis indicating direct and indirect effects of component characters on kapas yield in cotton

\begin{tabular}{|l|l|l|l|l|l|l|l|l|l|l|}
\hline Traits & $\mathbf{Y}_{\mathbf{1}}$ & $\mathbf{Y}_{\mathbf{2}}$ & $\mathbf{Y}_{\mathbf{3}}$ & $\mathbf{Y}_{\mathbf{4}}$ & $\mathbf{Y}_{\mathbf{5}}$ & $\mathbf{Y}_{\mathbf{6}}$ & $\mathbf{Y}_{\mathbf{7}}$ & $\mathbf{Y}_{\mathbf{8}}$ & $\mathbf{Y}_{\mathbf{9}}$ & $\mathbf{Y}_{\mathbf{1 0}}$ \\
\hline $\mathbf{Y}_{\mathbf{1}}$ & 0.0183 & 0.0050 & 0.2080 & 0.0032 & 0.0086 & -0.1098 & -0.0079 & 0.0783 & -0.0238 & $\mathbf{0 . 3 7 9 9}$ \\
\hline $\mathbf{Y}_{\mathbf{2}}$ & -0.0003 & -0.2688 & 0.0658 & 0.0049 & 0.0039 & 0.0064 & -0.0748 & 0.0652 & 0.022 & $\mathbf{- 0 . 1 7 5 8}$ \\
\hline $\mathbf{Y}_{\mathbf{3}}$ & 0.008 & -0.0373 & 0.4743 & 0.0132 & 0.0101 & -0.0680 & 0.1112 & -0.0797 & -0.0451 & $\mathbf{0 . 3 8 6 7 ^ { * * }}$ \\
\hline $\mathbf{Y}_{\mathbf{4}}$ & -0.0005 & 0.0120 & -0.0575 & -0.1091 & -0.005 & -0.0329 & -0.0134 & 0.0879 & 0.0375 & $\mathbf{0 . 5 8 1 0 ^ { * * * }}$ \\
\hline $\mathbf{Y}_{\mathbf{5}}$ & 0.004 & -0.0266 & 0.1226 & 0.0140 & 0.0389 & 0.0259 & 0.0857 & -0.0141 & -0.0323 & $\mathbf{0 . 2 1 8 2}$ \\
\hline $\mathbf{Y}_{\mathbf{6}}$ & 0.0029 & 0.0025 & 0.0471 & -0.0052 & -0.0015 & -0.6852 & 0.0339 & 0.5485 & 0.1030 & $\mathbf{0 . 0 4 6 0}$ \\
\hline $\mathbf{Y}_{\mathbf{7}}$ & 0.0003 & -0.0374 & -0.0982 & -0.0027 & -0.0062 & 0.0432 & -0.5375 & 0.1698 & 0.0607 & $\mathbf{- 0 . 4 0 8 0 ^ { * * }}$ \\
\hline $\mathbf{Y}_{\mathbf{8}}$ & 0.0021 & -0.0255 & -0.055 & -0.0139 & -0.0008 & -0.5464 & -0.1327 & 0.6880 & 0.1500 & $\mathbf{0 . 0 6 5 8}$ \\
\hline $\mathbf{Y}_{\mathbf{9}}$ & 0.0021 & 0.0284 & 0.1030 & 0.0197 & 0.0060 & 0.3393 & 0.1569 & -0.4961 & -0.208 & $\mathbf{- 0 . 0 4 8 7}$ \\
\hline
\end{tabular}

Residual effect $=0.80, *=$ Significant at $5 \%$ level of Probability, $* *=$ Significant at $1 \%$ level of Probability

$\begin{array}{lll}\mathrm{Y}_{1} & - & \text { Plant height }(\mathrm{cm}) \\ \mathrm{Y}_{2} & - & \text { Number of Sympodial branches per plant } \\ \mathrm{Y}_{3} & - & \text { Number of bolls/ plant } \\ \mathrm{Y}_{4} & - & \text { Boll weight }(\mathrm{g}) \\ & & \\ \mathrm{Y}_{9} & - & \text { Micronaire value }\left(10^{-6} \mathrm{~g} / \mathrm{in}\right)\end{array}$

$\mathrm{Y}_{5} \quad$ - $\quad$ Ginning outturn (\%)

$\mathrm{Y}_{6} \quad-\quad$ Span length $(\mathrm{mm})$

$\mathrm{Y}_{7} \quad$ - $\quad$ Uniformity ratio

$\mathrm{Y}_{8} \quad$ - $\quad$ Fibre strength(g/tex)

$Y_{10} \quad-\quad$ Seed cotton yield per plant $(g)$ discoveries of Pradeep et al. (2014), Asha et al. (2015) and Irfan et al. (2018). Likewise, Abdullah et al. (2016) and Memon et al. (2017).

\section{Phenotypic correlation}

The phenotypic connection of seed cotton yield with different part characteristics in this populace is introduced in Table 2. At phenotypic level, seed cotton yield per plant has shown huge positive relationship with number of bolls per plant $(0.3470)$ and boll weight (0.4763) trailed by non-huge positive connection with plant height $(0.1802)$, ginning outturn (0.1749) and span length (0.0364). These outcomes were in concurrence with the discoveries of Khan et al. (2010), Alkuddsi et al. (2013), Farooq et al. (2014), Reddy et al. (2015), Memon et al. (2017). On the other case, investigates negative relationship of seed cotton yield with boll weight and micronaire was given by Pujer et al. (2014).Seed cotton yield per plant was essentially and contrarily related with number of sympodial branches per plant (- 0.2601), fiber strength (- 0.5631) and consistency proportion ($0.3684)$. The trait micronaire $(-0.0618)$ has shown non-huge negative relationship at phenotypic level. Comparative outcomes were seen by Dahiphale et al. (2015) and Khokher et al. (2017). Were the researchers Ashok and Ravikesavan (2010) and Farooq et al. (2014) observed a negative relationship between's seed cotton yield and fiber strength. Unexpectedly, positive interrelation of range length, fiber strength, plant height and sympodial branches with seed cotton yield per plant was accounted for by Pradeep et al. (2014), Asha et al. (2015) and Irfan et al. (2018). Likewise, Abdullah et al. (2016) and Memon et al. (2017) noticed positive relationship of seed cotton yield per plant with plant stature.

\section{Path coefficient analysis}

The gauge of immediate and aberrant impacts of various yield contributing and build up quality attributes on seed cotton yield per plant was worked out through path analysis at the phenotypic level and alongside their phenotypic relationship is introduced in Table 3. The phenotypical path diagram for seed cotton yield per plant is given in Figure 1. The path investigation showed that fiber strength $(0.6880)$ and the number of bolls per plant (0.4743) had most noteworthy direct impact on seed cotton yield per plant. Comparable outcomes were accounted for by Salahuddin et al. (2010), Pujer et al. (2014), Asha et al. (2015), Reddy et al. (2015), Angadi et al. (2016) and Irfan et al. (2018). Though characteristics like the number of sympodial branches per plant (- 0.2688), boll weight (- 0.1091), range length (- 0.6852) and consistency proportion (- 0.5375) had a negative direct impact on yield. The immediate impacts of any remaining part characteristics on seed cotton 


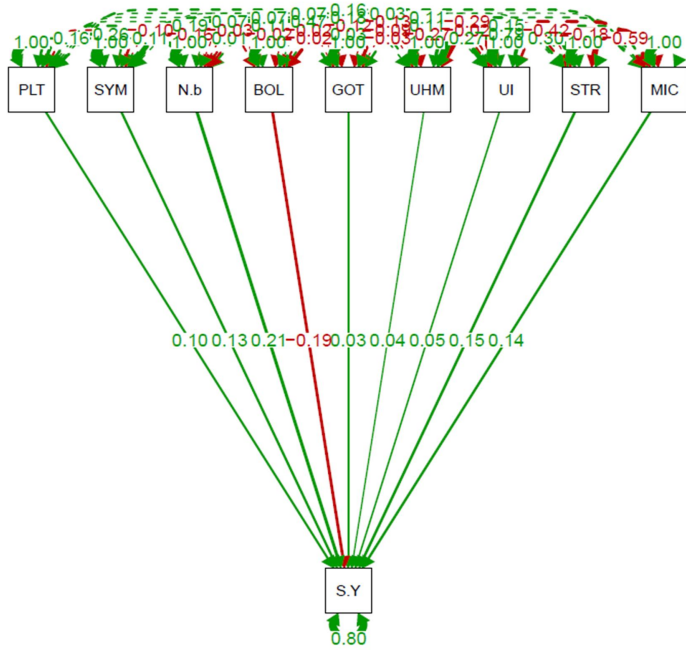

Figure 1: Phenotypical path diagram for seed cotton yield per plant

\begin{tabular}{|c|c|c|c|}
\hline LT & $\begin{array}{l}\text { Plant } \\
\text { height }(\mathrm{cm})\end{array}$ & GOT & $\begin{array}{l}\text { Ginning } \\
\text { outturn (\%) }\end{array}$ \\
\hline SYM & - $\begin{array}{l}\text { Number of } \\
\text { Sympodial } \\
\text { branches per } \\
\text { plant }\end{array}$ & UHM & $\begin{array}{r}\text { Span } \\
(\mathrm{mm})\end{array}$ \\
\hline .B & $\begin{array}{l}\text { Number of } \\
\text { bolls/ plant }\end{array}$ & UI & $\begin{array}{l}\text { - Uniformity } \\
\text { ratio }\end{array}$ \\
\hline $30 I$ & $\begin{array}{l}\text { Boll weight } \\
\text { (g) }\end{array}$ & STR & $\begin{array}{ll}\text { - } & \text { Fibre } \\
\text { strength(g/tex) }\end{array}$ \\
\hline I & $\begin{array}{ll}\text { - } & \text { Micronaire } \\
\text { value }\left(10^{-6} \mathrm{~g} / \mathrm{in}\right)\end{array}$ & S.Y & $\begin{array}{l}\text { Seed cotton } \\
- \\
\text { yield per plant } \\
(\mathrm{g})\end{array}$ \\
\hline
\end{tabular}

yield were positive however low. The positive circuitous impact of micronaire value with seed cotton yield per plant was most elevated through a

\section{References}

Abdullah, M., Numan, M., Shafique, M. S., Shakoor, A., Rehman, S., \& Ahmad, M. I. (2016). Genetic variability and interrelationship of various agronomic traits using correlation and path analysis in cotton (Gossypium hirsutum L.). Acad. J. Agric. Res, 4(6), 315-318.

Alkuddsi, Y., Rao, M. G., Patil, S. S., Joshi, M., \& Gowda, T. H. (2013). Correlation and path coefficient analysis between seed cotton yield and its attributing characters in intra hirsutum cotton hybrids. Molecular Plant Breeding, 4.

Angadi, C., Manjula, S. M., Patil, S. S., Madhura, C. Basavaradder, A. B., \& Santosh, H. B. (2016). Correlation and path coefficient analysis of yield component and fibre quality traits of upland cotton (Gossypium hirsutum L.). Int. J Agric. Sci. Res, 6(1), 171-176. number of bolls per plant, trailed by span length and consistency proportion. Neelima et al. (2008) showed that bolls per plant through boll weight and build up file, applied high certain circuitous impacts on seed cotton yield. Vinodhana et al. (2013) saw that boll weight applied beneficial outcomes on seed cotton yield per plant through fiber length, ginning rate and fiber strength. The backhanded impacts of any remaining segment attributes were immaterial.

\section{Conclusion}

Seed cotton yield per plant showed solid and positive relationship just as sure direct impacts on the yield contributing characters viz., symbodial branches per plant, number of bolls per plant, boll weight, ginning outturn, span length and micronaire value. Accordingly during future reproducing programs, these boundaries ought to be given push while making choice as they were significant characteristics of the seed cotton yield. The results discussed above indicate that correlation and direct and indirect effect estimates vary for different traits with variation in genetic material based on yield component traits and fibre properties. Hence, correlations and direct and indirect effect estimation would provide useful information for planning a successful breeding programme if the genetic material is grouped for yield and fibre quality characters and also it is essential to device suitable breeding methodologies for simultaneous improvement of both yield and quality parameters involving three way crosses, modified back crosses or recurrent selection.

Asha R., Ahamed M \& Kumar P. (2015). Character association and path coefficient analysis for yield and yield component traits in upland cotton. Journal of Cotton Research and Development. 29(1),31-35.

Dahiphale, K. D., Deshmukh, J. D., Bagade, A. B., \& Jadhav, A. B. (2015). Studies on genetic variability, correlation and path coefficient analysis in cotton (Gossypium hirsutum L.). International Journal of Tropical Agriculture, 33(1), 23-29.

Dewey, D. R., \& Lu, K. (1959). A Correlation and PathCoefficient Analysis of Components of Crested Wheatgrass Seed Production 1. Agronomy journal, 51(9), 515-518.

Farooq, J., Anwar, M., Riaz, M., Farooq, A., Mahmood, A., Shahid, M. T. H., ... \& Ilahi, F. (2014). Correlation and 
path coefficient analysis of earliness, fiber quality and yield contributing traits in cotton (Gossypium hirsutum L.). JAPS: Journal of Animal \& Plant Sciences, 24(3).

Irfan, A. R., Yujun, S., Jinying, L., \& Deguang, Y. (2018). Genetic variability, association analysis and path analysis in advance breeding material of Gossypium hirsutum L. Int. J Biosci, 12(1), 294-299.

Jawahar, S. G. T., \& Patil, B. R. (2017). Genetic variability and heritability study in F2 segregants of desi cotton for yield and its component traits. Int. J Curr. Microbio. App. Sci, 6(9), 2679-2684.

Khan, N. U., Marwat, K. B., Hassan, G., Farhatullah, S. B., Makhdoom, K., Ahmad, W., \& Khan, H. U. (2010). Genetic variation and heritability for cotton seed, fiber and oil traits in Gossypium hirsutum L. Pakistan Journal of Botany, 42(1), 615-625.

Memon, S., Gandahi, A. W. B. N., Yasir, T. A., Sarki, S. M., Wasaya, A., Mallano, I. A., ... \& Khetran, A. S. (2017). Evaluation of genetic divergence, character associations and path analysis in upland cotton genotypes. Pure and Applied Biology (PAB), 6(4), 1516-1521.

Neelima, S., \& Reddy, V. C. (2008). Genetic parameters of yield and fibre quality traits in American cotton (Gossypium hirsutum L.). Indian Journal of Agricultural Research, 42(1), 67-70.

Pradeep S., Satish Y \&Srinivasa Rao V. (2014). Character association and path coefficient analysis for yield and yield component traits in upland cotton (GossypiumhirsutumL.). Journal of Research ANGRAU. 42(4),32-35.
Pujer, S., Siwach, S. S., Deshmukh, J., Sangwan, R. S., \& Sangwan, O. (2014). Genetic variability, correlation and path analysis in upland cotton (Gossypium hirsutum L.). Electronic Journal of Plant Breeding, 5(2), 284-289.

Reddy, K.B., Reddy, V.C., Ahmed, M.L., \& Naidu T.C.M. Srinivasarao, V. (2015). Correlation and path coefficient analysis in upland cotton (Gossypium hirsutumL.).International Journal of Pure Applied Bioscience. 3(3),70-80.

Salahuddin, S., Abro, S., Kandhro, M. M., Salahuddin, L., \& Laghari, S. (2010). Correlation and path coefficient analysis of yield components of upland cotton (Gossypium hirsutum L.) sympodial. World Applied Sciences Journal, 8, 71-75.

Salahuddin, S., Abro, S., Kandhro, M. M., Salahuddin, L., \& Laghari, S. (2010). Correlation and path coefficient analysis of yield components of upland cotton (Gossypium hirsutum L.) sympodial. World Applied Sciences Journal, 8, 71-75.

Singh P \& Narayanan SS, (1993). Biometrial techniques in plant breeding. Kalyani Publishers, New Delhi.

Vinodhana, N. K., Gunasekaran, M., \& Vindhiyavarman, P. (2013). Genetic studies of variability, correlation and path coefficient analysis in cotton genotypes. Int. J. Pure App. Biosci, 1(5), 6-10. 